\title{
Stimulation of Collagen Gene Expression and Protein Synthesis in Murine Mesangial Cells by High Glucose Is Mediated by Autocrine Activation of Transforming Growth Factor- $\beta$
}

Fuad N. Ziyadeh, Kumar Sharma, Mark Ericksen, and Gunter Wolf *

Penn Center for Molecular Studies of Kidney Diseases, Renal-Electrolyte and Hypertension Division, Department of Medicine, University of Pennsylvania School of Medicine, Philadelphia, Pennsylvania 19104-6144; and *Department of Medicine, Division of Nephrology,

University of Hamburg, Hamburg D-20246, Germany

\begin{abstract}
Previous investigations have demonstrated that growing mesangial cells in high glucose concentration stimulates extracellular matrix synthesis and also increases the expression of TGF- $\beta$. We tested whether the stimulation of extracellular matrix production is mediated by autocrine activation of TGF- $\beta$, a known prosclerotic cytokine. Addition of neutralizing anti-TGF- $\beta$ antibody, but not normal rabbit IgG, significantly reduced the high glucose-stimulated incorporation of ${ }^{3}[\mathrm{H}]$ proline. Denaturing SDS-PAGE revealed that mainly collagen types I and IV were stimulated by high $(450 \mathrm{mg} / \mathrm{dl}$ ) D-glucose. This high glucose-mediated increase in collagen synthesis was reduced by the anti-TGF- $\beta$ antibody. Treatment of mesangial cells grown in normal $(100 \mathrm{mg} / \mathrm{dl})$ D-glucose with $2 \mathrm{ng} / \mathrm{ml}$ recombinant TGF- $\beta_{1}$ mimicked the effects of high glucose. Furthermore, the anti-TGF- $\beta$ antibody significantly reduced the increase in mRNA levels encoding $\alpha 2$ (I) and $\alpha$ ( IV) collagens induced by high glucose. Thus, the high glucose-stimulated increase of collagen production in mesangial cells is mediated, at least in part, by autocrine TGF- $\beta$ activation. We postulate that the interception of the glomerular activity of TGF- $\beta$ may be an effective intervention in the management of diabetic nephropathy. $(J$. Clin. Invest. 1994. 93:536-542.) Key words: extracellular matrix $\cdot$ collagen type I $\cdot$ collagen type IV $\bullet$ diabetic glomerulopathy $\cdot$ mouse kidney

\section{Introduction}

Progressive expansion of glomerular mesangial matrix resulting in diffuse intercapillary sclerosis is the most important structural lesion of diabetic glomerulopathy (1-4), one of the major causes of chronic renal disease. The degree of expansion of mesangial matrix in patients with insulin-dependent (type I) diabetes mellitus correlates closely with the progressive decline in the glomerular capillary surface area available for filtration,

Parts of this study were presented at the 25th Annual Meeting of the American Society of Nephrology, 15-18 November 1992, Baltimore, MD, and have been published in abstract form (1992. J. Am. Soc. Nephrol. 3:766).

Address correspondence to Fuad N. Ziyadeh, M.D., Renal-Electrolyte and Hypertension Division, University of Pennsylvania, Philadelphia, PA 19104-6144.

Received for publication 12 March 1993 and in revised form 6 October 1993.

J. Clin. Invest.

(c) The American Society for Clinical Investigation, Inc.

0021-9738/94/02/0536/07 \$2.00

Volume 93, February 1994, 536-542 and hence with the glomerular filtration rate (5-7). In experimental animal models of diabetic renal involvement, evidence has been accumulating that increased synthesis of several extracellular matrix components is a relatively early feature of the disease (reviewed in references $4,8,9$ ). Increased steady-state mRNA levels encoding collagen, laminin, and fibronectin have been described in renal cortical specimens (10-13) and, more recently, in isolated whole glomeruli (14). It has been proposed that many abnormalities of the diabetic milieu may contribute to glomerulosclerosis; these include adaptive changes in glomerular hemodynamics with an increase in transcapillary hydraulic pressure, increased nonenzymatic glycosylation products, activation of the polyol pathway, and alterations in hormonal balance and other biochemical abnormalities $(1,4,8,9$, $15,16)$. However, recent in vitro studies, first in tubular epithelial cells (17) and subsequently in glomerular cells (18-23), have provided supportive evidence that high ambient glucose per se can stimulate the synthesis of extracellular matrix components. In mesangial cells, Ayo and colleagues were the first to describe that cells cultured in a high glucose concentration accumulated more fibronectin, laminin, and type IV collagen compared with cells grown in a lower glucose concentration (18). The increase in production of these extracellular matrix components was associated with an increase in their respective steady-state mRNA levels (19). These and several other subsequent studies on glomerular cells in culture (20-23) have corroborated the notion that high ambient glucose plays a major role in promoting the production and accumulation of extracellular matrix components in diabetic glomerulopathy.

We have been interested in the molecular mechanisms that underlie the effects of ambient glucose on cellular growth and extracellular matrix production in different types of renal cells in culture $(16,17,24-26)$. Our recent studies in murine mesangial cells in culture revealed that raising the D-glucose concentration in the serum-free media from 100 to $450 \mathrm{mg} / \mathrm{dl}$ resulted in a transient stimulation of cell proliferation after $24-48 \mathrm{~h}$ but had a sustained growth inhibitory effect after $72 \mathrm{~h}$ of incubation (26). This late suppression of proliferation was associated with an increase in levels of transcripts encoding TGF- $\beta$ after $48 \mathrm{~h}$ of exposure to high glucose. Furthermore, a neutralizing antibody directed against TGF- $\beta$ prevented the late inhibitory effects of high glucose on mesangial cell proliferation (26). Since TGF- $\beta$ has been widely recognized to be a major promoter of extracellular matrix production (27-32), we postulated that this autacoid may mediate the stimulatory effects of high glucose on the synthesis of extracellular matrix in mesangial cells. Our present study demonstrates that the stimulation by high glucose of endogenous TGF- $\beta$ bioactivity in murine mesangial cells is largely responsible for the observed increase in collagen gene expression and protein synthesis. 


\section{Methods}

Cell culture. The present studies were performed on an immortalized, differentiated murine mesangial cell (MMC) ${ }^{1}$ line that was originally isolated from kidneys of 8- to 10 -wk-old $\mathrm{SJL} / \mathrm{J}\left(\mathrm{H}-2^{\mathrm{s}}\right)$ normal mice (33). MMCs were subsequently transformed with noncapsid forming SV-40 virus to establish a permanent cell line (33). Cells were grown in DME (GIBCO BRL, Gaithersburg, MD) containing 10\% FCS, 100 $\mathrm{U} / \mathrm{ml}$ penicillin, $100 \mu \mathrm{g} / \mathrm{ml}$ streptomycin, and $2 \mathrm{mM}$ supplemented glutamine. Cells were passaged every $72-96 \mathrm{~h}$ by light trypsinization.

Previous studies have demonstrated that this cell line exhibits many features of differentiated mesangial cells; the cells stain positive for Thy 1 antigen, desmin, vimentin, and collagens type I and IV, but fail to bind antibody directed against the proximal tubular nephritogenic 3M1 antigen (33). Moreover, MMCs express receptors for angiotensin II (33), and they also increase their cellular cGMP content after stimulation with atrial natriuretic peptide (34). Pilot experiments demonstrated that MMCs exhibit similar patterns of growth behavior and extracellular matrix production in response to elevated glucose concentration as nontransformed mesangial cells.

Total $^{3}[\mathrm{H}]$ proline incorporation into MMC. To gain insight into the kinetics of high glucose-mediated production of extracellular matrix components in MMCs, we first examined the time-course of incorporation of ${ }^{3}[\mathrm{H}]$ proline into TCA-precipitable proteins (33). Proline is one of the major constituents of collagen, and it is preferentially incorporated into collagens type I and IV in MMCs (33). For these experiments, $10^{5}$ cells / well were plated into 24-well cell culture plates (Nunclon, Denmark) in DME containing $100 \mathrm{mg} / \mathrm{dl}$ D-glucose $(5.6 \mathrm{mM})$ and $10 \% \mathrm{FCS}$, and at confluence, they were made quiescent by incubation for $48 \mathrm{~h}$ in DME with a D-glucose concentration of $100 \mathrm{mg} / \mathrm{dl}$ in the absence of serum. After this time period, the media were changed to fresh serum-free DME with either 100 or $450 \mathrm{mg} / \mathrm{dl}(25 \mathrm{mM}) \mathrm{D}$-glucose. Some cells received DME with $100 \mathrm{mg} / \mathrm{dl}$ D-glucose plus 350 $\mathrm{mg} / \mathrm{dl} \mathrm{D}$-mannitol to achieve equal final medium osmolarity as that containing $450 \mathrm{mg} / \mathrm{dl}$ D-glucose. Additional cells were incubated with normal-or high-glucose media in the presence of $30 \mu \mathrm{g} / \mathrm{ml}$ neutralizing rabbit antiporcine TGF- $\beta$ antibody (IgG fractions, neutralizes TGF- $\beta_{1}$ and TGF- $\beta_{2} ;$ R \& D Systems, Minneapolis, MN) or a similar concentration of normal rabbit IgG. For the last $12 \mathrm{~h}$ of culture, $1 \mu \mathrm{Ci}^{3}[\mathrm{H}]-$ proline $\left(\mathrm{L}-(2,3,4,5)-{ }^{3}[\mathrm{H}]\right.$ proline, $130 \mathrm{Ci} / \mathrm{mmol}$; Amersham Corp., Arlington Heights, IL) was added to each well. After $24,48,72$, or $96 \mathrm{~h}$ of exposure to the different culture conditions, cells were washed three times in ice-cold PBS, precipitated twice in ice-cold $10 \%$ TCA, redissolved in $500 \mu$ l of $0.5 \mathrm{M} \mathrm{NaOH}$ with $0.1 \%$ Triton X-100, and counted for $\beta$ emissions. Additional cells plated in parallel wells were directly scraped off the plate with a rubber policeman and counted in an automated cell counter (Coulter Electronics, Hialeah, FL). Proline incorporation was expressed as $\mathrm{cpm} / 10^{6}$ cells.

$S D S-P A G E$ of labeled proteins. Evaluation of the specific type of extracellular matrix produced by MMCs was performed by separation of ${ }^{3}[\mathrm{H}]$ proline-labeled proteins on SDS-PAGE and comparison with standard collagens $(33,35,36)$. In $75-\mathrm{cm}^{2}$ cell culture flasks, quiescent, confluent cells were incubated for 48 or $72 \mathrm{~h}$ in serum-free DME with normal $(100 \mathrm{mg} / \mathrm{dl})$ or high $(450 \mathrm{mg} / \mathrm{dl})$ D-glucose in the presence or absence of $30 \mu \mathrm{g} / \mathrm{ml}$ neutralizing anti-TGF- $\beta$ antibody. Control rabbit IgG $(30 \mu \mathrm{g} / \mathrm{ml})$ was included as control in some flasks. As positive control, additional flasks were supplemented with $2 \mathrm{ng} / \mathrm{ml}$ recombinant human TGF- $\beta_{1}$ (R \& D Systems). L-ascorbic acid and the crosslinking inhibitor $\beta$-aminopropionitrile ( $50 \mu \mathrm{g} / \mathrm{ml}$ of each ) as well as 10 ${ }_{\mu} \mathrm{Ci}^{3}[\mathrm{H}]$ proline were also added to each flask (33). At the end of the culture period, the cell culture medium and the cells were harvested separately in a cocktail of protease inhibitors $(15 \mathrm{mM} \mathrm{N}$-ethylmaleimide, $20 \mathrm{mM}$ EDTA, and $1 \mathrm{mM}$ phenylmethylsulfonylfluoride). After harvesting the culture medium, MMCs were directly lysed in 5\% acetic

1. Abbreviations used in this paper: GAPDH, glyceraldehyde-3-phosphate dehydrogenase; HG, high glucose; MMC, murine mesangial cell; NG, normal glucose. acid on ice, centrifuged, and the supernatant was saved. The proteins from the culture supernatants and the cell lysates were precipitated by adding absolute ethanol (final concentration $33 \%$, vol/vol) at $4^{\circ} \mathrm{C}$ for $24 \mathrm{~h} \mathrm{(36)}$. The samples were centrifuged at $4^{\circ} \mathrm{C}$, the pellets were dissolved in Laemmli buffer with 5\% 2-mercaptoethanol, boiled for 2 min, centrifuged again, and the protein concentration of the supernatants was measured by a modification of the Lowry method which is not affected by the concentrations of SDS and 2-mercaptoethanol used in this study (23). Equal amounts of protein ( $5 \mu \mathrm{g} /$ lane) were separated under denaturing conditions on a $12 \%$ SDS-polyacrylamide gel with a $4 \%$ stacking gel (37). After staining with Coomassie blue, the gel was soaked in Amplify (Amersham Corp.), dried under vacuum and fluorographed at $-70^{\circ} \mathrm{C}$ for $48 \mathrm{~h}$ (media supernatants) or $4 \mathrm{~d}$ (cell lysates). Bands were examined by comparison with high molecular weight markers, as well as collagen standards for types I and IV and fibronectin, which were run in parallel on the gel (33).

Northern hybridization. Rested MMCs ( $10^{7}$ cells) were cultured for $24,48,72$, or $96 \mathrm{~h}$ in serum-free DME containing either $100 \mathrm{mg} / \mathrm{dl}$ or $450 \mathrm{mg} / \mathrm{dl} \mathrm{D}$-glucose. Some MMCs were also incubated in the presence of the neutralizing anti-TGF- $\beta$ antibody $(30-50 \mu \mathrm{g} / \mathrm{ml})$ or control rabbit $\mathrm{IgG}(30-50 \mu \mathrm{g} / \mathrm{ml})$. At the end of the incubation period, cells were washed in RNAse-free PBS ( $\mathrm{pH} 7.2$ ), and directly lysed and denatured in $4 \mathrm{M}$ guanidinium thiocyanate, $25 \mathrm{mM}$ sodium citrate, $\mathrm{pH} 7.0$, $0.5 \%$ sarcoysl, and $0.1 \mathrm{M} 2$-mercaptoethanol. Total RNA was isolated as described by repeated phenol-chloroform extractions $(26,38)$. A total of $20-40 \mu \mathrm{g}$ RNA was separated on a $1.2 \%$ agarose gel containing $2.2 \mathrm{M}$ formaldehyde. The RNA was electroblotted onto nylon membranes (Gene Screen; Du Pont-NEN, Boston, MA), ultraviolet wave cross-linked, and the membrane was prehybridized overnight at $42^{\circ} \mathrm{C}$ in a buffer containing $5 \times$ SSPE $(1 \times$ SSPE $=149 \mathrm{mM} \mathrm{NaCl}, 10 \mathrm{mM}$ $\mathrm{NaH}_{2} \mathrm{PO}_{4}, 1 \mathrm{mM}$ EDTA ), $5 \times$ Denhardt's ( $50 \times$ Denhardt's $=1 \% \mathrm{Fi}$ coll, $1 \%$ polyvinylpyrrolidone, $1 \%$ bovine serum albumin ), $0.1 \%$ SDS, $100 \mu \mathrm{g} / \mathrm{ml}$ denatured salmon sperm DNA, and 50\% (vol/vol) formamide. All cDNA inserts were separated from their plasmids in low melt agarose and labeled with $5 \mu \mathrm{Ci}^{32}[\mathrm{P}]$ deoxycytidine 5 '-triphosphate $(3,000 \mathrm{Ci} / \mathrm{mmol}$; Amersham Corp.) using random priming (Amersham Corp.). The cDNA probes used were a $0.85-\mathrm{kb}$ Xhol fragment encoding murine $\alpha 2$ (I) procollagen (39), and a 0.66-kb PstI fragment encoding murine $\alpha$ (IV) collagen (40). The labeled cDNAs were separated from unincorporated nucleotides by Sephadex G-50 spin columns (Boehringer Mannheim, Indianapolis, IN), and membranes were hybridized with $10^{6} \mathrm{cpm} / \mathrm{ml}$ probe in hybridization buffer (same as prehybridization buffer, except that $2 \times$ Denhardt's was used) for $24 \mathrm{~h}$ at $42^{\circ} \mathrm{C}$. After hybridization, blots were washed for $30 \mathrm{~min}$ in $2 \times \operatorname{SSC}(20 \times \operatorname{SSC}=3 \mathrm{M} \mathrm{NaCl}, 0.3 \mathrm{M}$ sodium citrate, $\mathrm{pH} 7.0)$ with $0.1 \%$ SDS at $22^{\circ} \mathrm{C}$, followed by two 15 -min washes in $0.1 \times$ SSC with $0.1 \% \mathrm{SDS}$ at $62^{\circ} \mathrm{C}$. The membranes were then autoradiographed with intensifying screens (Du Pont, Wilmington, DE) at $-70^{\circ} \mathrm{C}$ for $10-14$ d. Blots were then stripped for $2 \mathrm{~h}$ at $65^{\circ} \mathrm{C}$ with $5 \mathrm{mM}$ Tris, $0.2 \mathrm{mM}$ EDTA ( $\mathrm{pH} 8.0$ ), and $5 \%$ sodium pyrophosphate, and subsequently rehybridized with cDNA fragment encoding rat glyceraldehyde-3-phosphate dehydrogenase (GAPDH) $(17,24,33)$ to account for small variations in loading and transfer. Exposed films were scanned with a laserdensitometer (Hoefer Scientific Instruments, San Francisco, CA), and collagen mRNA levels were calculated relative to those of GAPDH. Measurements in normal-glucose cultures were assigned a relative value of 1 , or $100 \%(24,26)$.

Statistical analysis. Data are presented as the mean $\pm \mathrm{SE}$, with $n$ as the number of different experiments. Groups were compared by ANOVA, and the Wilcoxon-Mann-Whitney test was used to compare individual groups; $P<0.05$ was considered significant.

\section{Results}

${ }^{3}[H]$ proline incorporation studies. Fig. 1 demonstrates that raising the D-glucose concentration of serum-free DME from 100 to $450 \mathrm{mg} / \mathrm{dl}$ for $\geq 48 \mathrm{~h}$ induced a significant increase in 


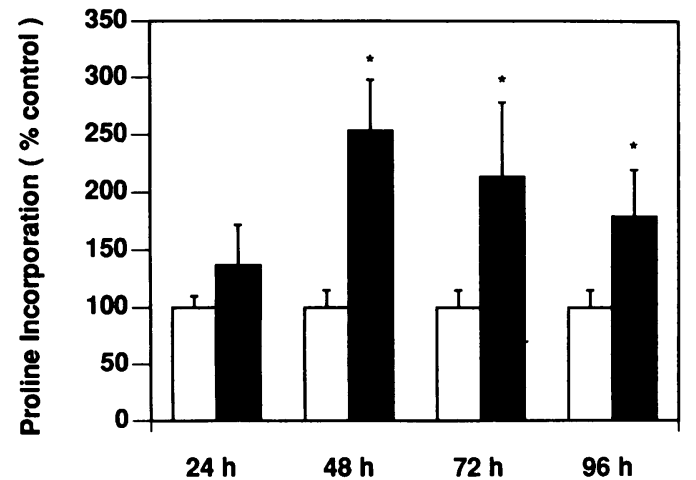

Figure 1. Time course of ${ }^{3}[\mathrm{H}]$ proline incorporation. Quiescent MMCs were grown in serum-free medium containing either normal $(100 \mathrm{mg} / \mathrm{dl})$ or high $(450 \mathrm{mg} / \mathrm{dl}) \mathrm{D}$-glucose. Significant stimulation of ${ }^{3}[\mathrm{H}]$ proline incorporation into proteins from MMCs grown in high glucose (closed bars) after $48-96 \mathrm{~h} .{ }^{*} P<0.01$ vs cells grown in normal glucose (open bars); $n=3$ experiments, six replicates each.

${ }^{3}[\mathrm{H}]$ proline incorporation into TCA-precipitable proteins. At $48 \mathrm{~h}$, the increase in proline incorporation was $\sim 2.5$-fold, and most of this effect persisted at $72 \mathrm{~h}$ when the stimulation was at least twofold. At $96 \mathrm{~h}$, the stimulation of ${ }^{3}[\mathrm{H}]$ proline incorporation by high glucose was $79 \%$ higher than in cells grown in normal glucose (Fig. 1). It should be noted, however, that incubations in serum-free DME for a total of $6 \mathrm{~d}$ (which would also include the $48 \mathrm{~h}$ of resting before changing the media to high or normal glucose) were often not well tolerated by the cells and required cell passage and/or serum rescue.

This stimulation of ${ }^{3}[\mathrm{H}]$ proline incorporation could not be simply attributed to a rise in the osmolarity of the medium containing $450 \mathrm{mg} / \mathrm{dl}$ D-glucose, since the addition of $350 \mathrm{mg} /$ dl D-mannitol to the normal glucose-containing medium failed to induce an increase in proline incorporation ( $10.01 \pm 0.45$ $\times 10^{3} \mathrm{cpm} / 10^{6}$ cells, $\left.48 \mathrm{~h}, n=6\right)$ as compared with cells grown in $100 \mathrm{mg} / \mathrm{dl} \mathrm{D}$-glucose $\left(9.52 \pm 0.75 \times 10^{3} \mathrm{cpm} / 10^{6}\right.$ cells, NS $)$. These results indicate that the high $\mathrm{D}$-glucose concentration in the medium stimulated de novo synthesis of proline-rich proteins.

We previously demonstrated that high glucose also increased TGF- $\beta_{1}$ transcript levels and stimulated the production of bioactive TGF- $\beta$ in MMCs (26). Since TGF- $\beta$ was shown in various systems to increase production of extracellular matrix proteins $(27,28,30-32,41)$, we therefore tested our hypothesis that induction by high glucose of endogenous TGF- $\beta$ in MMCs is responsible for the stimulation of ${ }^{3}[\mathrm{H}]$ proline incorporation. This notion was evaluated by examining the response to treatment with a neutralizing anti-TGF- $\beta$ antibody, which we had previously shown to exhibit a potent neutralizing activity (24, 26). As demonstrated in Fig. 2, coincubation of MMCs grown in $450 \mathrm{mg} / \mathrm{dl}$ D-glucose with the neutralizing anti-TGF- $\beta$ antibody for $72 \mathrm{~h}$ significantly reduced (but did not abolish) the stimulatory effect of high glucose on ${ }^{3}[\mathrm{H}]$ proline incorporation. Basal incorporation in cells grown in normal glucose concentration was not significantly reduced by the antibody (after 72 h, Fig. 2; or after 24,48 , or 96 h, data not shown). Moreover, the response in high glucose concentration was specific for the anti-TGF- $\beta$ antibody, since isotypic normal rabbit IgG failed to inhibit the stimulated proline incorporation in high glucose-containing medium (Fig. 2 and data not shown).

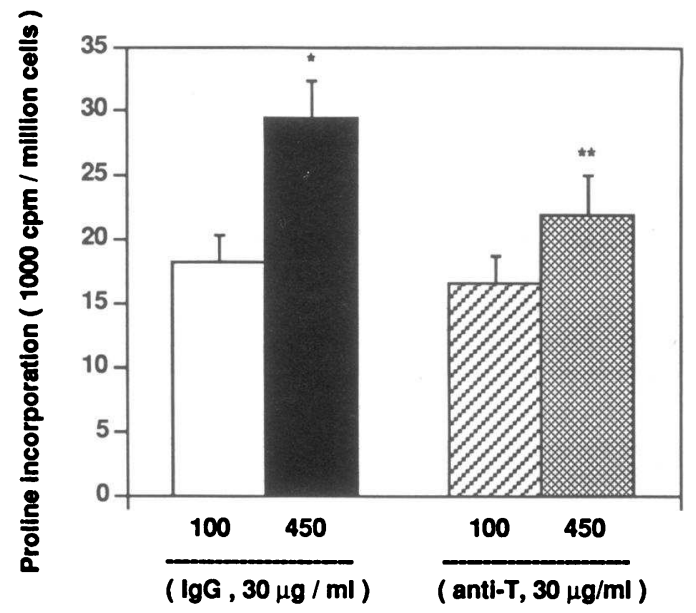

Figure 2. TGF- $\beta$ and proline incorporation. Treatment with $30 \mu \mathrm{g} / \mathrm{ml}$ neutralizing anti-TGF- $\beta$ antibody (anti-T) for $72 \mathrm{~h}$ abrogated the high glucose-stimulated incorporation of ${ }^{3}[\mathrm{H}]$ proline into extracellular matrix proteins. The same concentration of normal rabbit IgG had no significant effect. ${ }^{*} P<0.01$ vs cells grown in normal glucose. ${ }^{* *} P<0.05$ vs cells treated with control $\mathrm{IgG}, n=6$.

There was absence of any effect of normal rabbit IgG on the cells grown in $100 \mathrm{mg} / \mathrm{dl} \mathrm{D}$-glucose for 24-96 h (not shown). In additional studies, the anti-TGF- $\beta$ antibody also significantly reduced ${ }^{3}[\mathrm{H}]$ proline incorporation in cells grown in high glucose for $96 \mathrm{~h}$ ( not shown).

$S D S-P A G E$ of labeled proteins. To directly assess the types of collagens stimulated by high glucose, cell culture supernatant and lysates of pulse-labeled MMCs were separated by SDS-PAGE and compared to standard collagens run in parallel. Fig. 3 demonstrates that most of the synthesized collagen in the presence of the cross-linking inhibitor $\beta$-amino propionitrile was released into the culture medium supernatant (lanes 1-6) and were not retained in the cell lysates (lanes 7 and 8). This finding confirms previous studies on MMCs (33) and other mesangial cells in culture $(21,42)$. Note also that since most of the extracellular matrix proteins are secreted into the culture supernatant, incubation of MMCs in high glucose medium had only little effect on other (intracellular) proteins labeled with ${ }^{3}[\mathrm{H}]$ proline and harvested from cell lysates (lane 8 vs lane 7$)$. In accordance with other investigations $(35,36)$, we also found that under our in vitro culture conditions the MMC cell line produced more type I than type IV collagen (Fig. 3, lanes 1-6). Moreover, the MMCs grown for $72 \mathrm{~h}$ in high glucose more than doubled their production of the $\alpha 1$ and $\alpha 2$ chains of type I, as well as type IV collagens (lane 2 vs lane 1 ).

Addition of exogenous TGF- $\beta_{1}(2 \mathrm{ng} / \mathrm{ml})$ to medium containing $100 \mathrm{mg} / \mathrm{dl}$ glucose resulted in stimulation of collagens types I and IV (Fig. 3, lane 5 vs lane 1 ), and thus mimicked the effect of $450 \mathrm{mg} / \mathrm{dl}$ glucose (lane 5 vs lane 2). On the other hand, addition of exogenous TGF- $\beta_{1}$ to MMCs that were grown in high glucose resulted in only a small increase in the synthesis of types I and IV collagens compared with cells grown in high glucose without exogenous TGF- $\beta_{1}$ (Fig. 3, lane 6 vs lane 2). An increase by high glucose of endogenous TGF- $\beta$-like activity is one possible explanation for the latter finding. The likelihood of such an event was substantiated by the observation that addition of the anti-TGF- $\beta$ antibody nearly abolished the high glucose-mediated increase in collagen synthesis (Fig. 


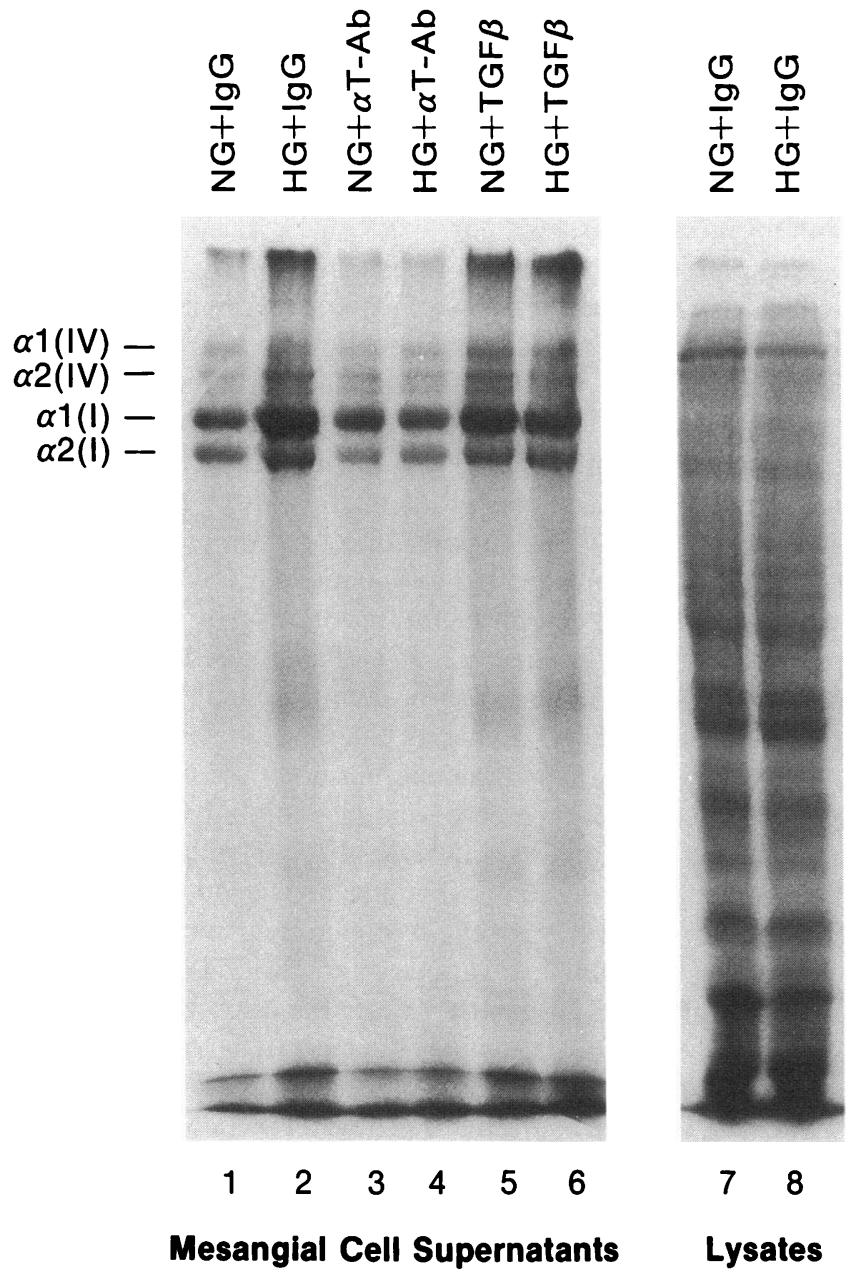

Figure 3. Separation of ${ }^{3}[\mathrm{H}]$ proline labeled proteins on a $12 \%$ SDS-polyacrylamide gel with subsequent fluorography. Positions for collagen chains were obtained from standard murine collagens run in parallel and stained with Coomassie blue. The majority of collagen types I and IV is secreted into the culture supernatant in the presence of the cross-linking inhibitor $\beta$-aminopropionitrile and did not appear in cell lysates (lane 7 and 8 ). MMCs grown for $48 \mathrm{~h}$ in high glucose $(H G)(450 \mathrm{mg} / \mathrm{dl})$ produced more collagen type I and IV chains compared with normal glucose $(N G)(100 \mathrm{mg} / \mathrm{dl})$ (lanes $l$ and 2$)$. Treatment with $30 \mu \mathrm{g} / \mathrm{ml}$ normal rabbit IgG had no effect on this stimulation (lanes $l$ and 2 ). In contrast, the anti-TGF- $\beta$ antibody $(30 \mu \mathrm{g} / \mathrm{ml}, \alpha \mathrm{T}-\mathrm{Ab})$ abolished the high glucose-stimulated production of collagen chains (lane 4), but had little effect on baseline production of collagens in normal glucose (lane 3). Treatment of MMCs with $2 \mathrm{ng} / \mathrm{ml}$ TGF- $\beta_{1}$ mimicked the effect of high glucose (lanes 5 and 6 ). High glucose medium had only small effects on other ${ }^{3}[\mathrm{H}]$ proline labeled proteins in whole cell lysates and which were not secreted into the supernatants (lanes 7 and 8 ). This gel is representative of two independent experiments with qualitatively similar results.

3 , lane 4 vs lane 2), but did not influence basal synthesis of collagen in medium with $100 \mathrm{mg} / \mathrm{dl}$ glucose (lane 3 vs lane 1 ). Not shown is the absence of any effect of normal rabbit IgG on collagen synthesis in either normal or high glucose media.

Effects of high glucose and anti-TGF- $\beta$ antibody on collagen gene expression. We first tested whether high glucose has a stimulatory effect on steady-state mRNA levels for type I collagen, then confirmed that high glucose in MMCs, as in other mesangial cell cultures (19), increases the steady-state mRNA levels for type IV collagen. The possible role for endogenous TGF- $\beta$ production in mediating these effects was also tested. Table I summarizes the results of different experiments examining the effects of high glucose concentration and anti-TGF- $\beta$ antibody on relative $\alpha 2$ (I) procollagen. Cells cultured in high vs normal glucose for $48 \mathrm{~h}$ expressed more than twofold higher levels of transcripts encoding the $\alpha 2$ (I) chain relative to GAPDH. The addition of the neutralizing anti-TGF- $\beta$ antibody significantly attenuated the high glucose-stimulated increase in $\alpha 2$ (I) mRNA, to levels which were similar to those in normal glucose media ( Table I). Note the absence of any inhibitory effect of normal rabbit IgG on $\alpha 2$ (I) and $\alpha$ l (IV) mRNA levels as compared with levels in cells grown in either 100 ( Table I) or $450 \mathrm{mg} / \mathrm{dl}$ D-glucose alone (not shown). In general, similar findings were obtained when the mRNA for the $\alpha 1$ chain of type IV collagen was examined (Table I).

Fig. 4 is a representative northern blot of RNA hybridized with a cDNA probe encoding murine $\alpha 2(\mathrm{I})$ procollagen, followed by hybridization with a probe encoding rat GAPDH. The stimulation by high glucose of $\alpha 2$ (I) transcript levels was evident as early as $24 \mathrm{~h}$ (lane 2 vs lane 1 ) and it persisted at $48 \mathrm{~h}$ (lane 6 vs lane 5 ) and at $72 \mathrm{~h}$ (not shown). The addition of 50 $\mu \mathrm{g} / \mathrm{ml}$ neutralizing anti-TGF- $\beta$ antibody markedly attenuated the high glucose-stimulated increase in $\alpha 2$ (I) mRNA levels after $48 \mathrm{~h}$ of culture in high glucose (Fig. 4 , lane 8 vs lane 6 ); there was only a modest attenuation, if any, after $24 \mathrm{~h}$ (lane $4 \mathrm{vs}$ lane 2). In normal glucose-containing media, anti-TGF- $\beta$ antibody had no inhibitory effect on $\alpha 2$ (I) procollagen mRNA level at $24 \mathrm{~h}$ (lane 3 vs lane 1 ), but decreased the mRNA level at $48 \mathrm{~h}$ (lane 7 vs lane 5 ); this may indicate that the cells elaborate basal levels of bioactive TGF- $\beta$ in normal glucosecontaining media. These studies provide the first evidence that high ambient glucose stimulates collagen type I gene expression in mesangial cell culture. Moreover, this response appears to be mediated, at least in part, by bioactivation of endogenous TGF- $\beta$.

Fig. 5 is a representative Northern blot of RNA hybridized with cDNA probes encoding murine $\alpha$ l (IV) collagen and rat GAPDH. Note first that after only $24 \mathrm{~h}$ in culture, the $\alpha 1$ (IV) mRNA level was not appreciably modulated by exposure to either high glucose or to anti-TGF- $\beta$ antibody (Fig. 5, lanes 1-4). In contrast, and after a lag period of $48 \mathrm{~h}$ of culture in high glucose concentration, the steady-state level of the $\alpha$ l (IV) mRNA relative to GAPDH mRNA level was increased by ap-

Table I. Effects of High Glucose and Anti-TGF- $\beta$ Antibodies on Collagen Gene Expression in Mesangial Cells

\begin{tabular}{lcccr}
\hline & $\mathrm{NG} / \mathrm{lgG}$ & $\mathrm{HG} / \mathrm{lgG}$ & $\mathrm{NG} / \alpha \mathrm{T}$ & $\mathrm{HG} / \alpha \mathrm{T}$ \\
\hline$\alpha 2(\mathrm{I})$ & $109 \pm 5 \%$ & $228 \pm 17 \% *$ & $95 \pm 26 \%$ & $118 \pm 10 \%$ \\
$\alpha \mathrm{I}(\mathrm{IV})$ & $109 \pm 8 \%$ & $210 \pm 31 \% *$ & $93 \pm 30 \%$ & $90 \pm 12 \%$ \\
\hline
\end{tabular}

Values are mean $\pm \mathrm{SE}$ of ratios of densitometric scanning of northern blot autoradiograms measuring mRNA of $\alpha 2$ (I) and corresponding GAPDH, and of $\alpha$ I(IV) and corresponding GAPDH in MMC cultured in serum-free medium for $48 \mathrm{~h}$ in 100 or $450 \mathrm{mg} / \mathrm{dl} \mathrm{D}$-glucose ( NG and HG, respectively) plus $50 \mu \mathrm{g} / \mathrm{ml}$ normal rabbit IgG or neutralizing anti-TGF- $\beta$ antibodies (IgG and $\alpha \mathrm{T}$, respectively). Data are from four different experiments and are expressed as percent of control, where control is cells grown in $100 \mathrm{mg} / \mathrm{dl} \mathrm{D}$-glucose without IgG or $\alpha \mathrm{T} .{ }^{*} P<0.01$ vs control. 


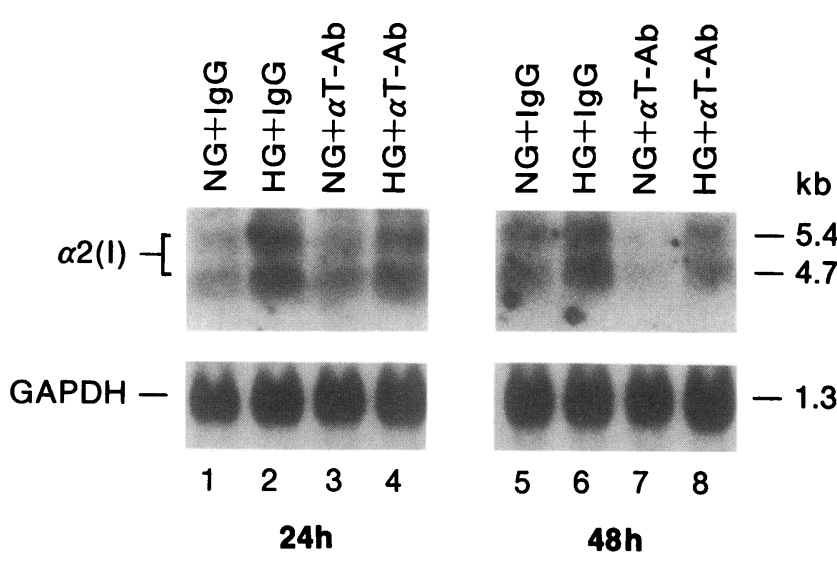

Figure 4. Collagen type I gene expression. A representative northern blot of RNA isolated from MMCs grown for $24-48 \mathrm{~h}$ in the presence of $\mathrm{HG}$ or NG and probed with cDNA encoding the $\alpha 2(\mathrm{I})$ chain procollagen type I. High glucose $(450 \mathrm{mg} / \mathrm{dl})$, as compared with normal glucose ( $100 \mathrm{mg} / \mathrm{dl}$ ), increased steady-state mRNA levels for $\alpha 2$ (I) procollagen relative to the housekeeping gene GAPDH. The antiTGF- $\beta$ antibody ( $\alpha \mathrm{T}-\mathrm{Ab}, 50 \mu \mathrm{g} / \mathrm{ml}$ ) reduced the increase in $\alpha 2(\mathrm{I})$ mRNA expression. Control cells were cultured in the presence of 50 $\mu \mathrm{g} / \mathrm{ml}$ normal rabbit IgG.

proximately twofold (lane 6 vs lane 5 ), and this effect was reduced by concomitant treatment with $50 \mu \mathrm{g} / \mathrm{ml}$ anti-TGF- $\beta$ antibody (lane 8 vs lane 6 ). At this high dose of the antibody, the $\alpha$ (IV) mRNA was also reduced to some extent in normal glucose at $48 \mathrm{~h}$ (lane 7 vs lane 5), suggesting the presence of basal levels of bioactive TGF- $\beta$ in normal glucose-containing. media. Note, however, that the anti-TGF- $\beta$ antibody had no demonstrable effect on the levels of transcripts encoding GAPDH, suggesting that the antibody was not nonspecifically repressive.

\section{Discussion}

The main results of this study show that high glucose concentration in the culture medium of a murine mesangial cell line

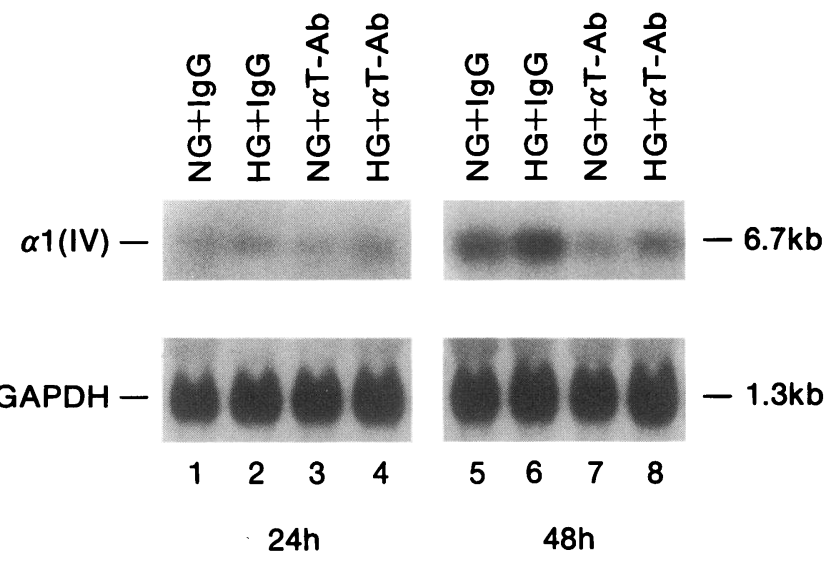

Figure 5. Collagen type IV gene expression. A representative northern blot probed with a cDNA encoding $\alpha$ l (IV) collagen. The details of the experiment are similar to those given in the legend to Fig. 4. The high glucose-stimulated mRNA level for type IV collagen at $48 \mathrm{~h}$ was virtually abolished by the anti-TGF- $\beta$ antibody. At this high dose of the antibody, $\alpha$ l(IV) mRNA was also reduced in normal glucose at $48 \mathrm{~h}$. increases de novo protein synthesis especially collagens types I and IV; this action mimics the effects of recombinant TGF- $\beta$ on mesangial cell collagen synthesis. In fact, the stimulation by high glucose of collagen gene expression and protein synthesis appears to be largely mediated, at least in part, by bioactivation of endogenous TGF- $\beta$.

The present study was performed to test our hypothesis that the stimulation by high glucose of extracellular matrix protein synthesis in a murine mesangial cell line is mediated by increased autocrine synthesis and/or activation of endogenous TGF- $\beta$. The rationale for conducting these studies relates to the results of our previous studies investigating the effects of glucose concentration on the proliferative growth response of MMCs (26). Raising the glucose concentration in the serumfree culture medium from 100 to $450 \mathrm{mg} / \mathrm{dl}$ produced a transient stimulation in cell proliferation followed by a sustained growth inhibitory effect after 72-96 h of incubation (26). Concomitantly, Northern blot analysis demonstrated that TGF- $\beta_{1}$ mRNA was induced by $450 \mathrm{mg} / \mathrm{dl}$ glucose after a lag period of $\geq 48 \mathrm{~h}$. Moreover, a neutralizing antibody directed against TGF- $\beta_{1}$ and TGF- $\beta_{2}$ prevented the late inhibitory effects of high glucose on proliferation, suggesting that this inhibitory effect is mediated by enhanced endogenous synthesis and/or bioactivation of TGF- $\beta$ (26). Our present investigations strongly suggest that bioactivation of autocrine TGF- $\beta$ in mesangial cells also partly mediates yet another important effect of high glucose in these cells, namely the increased biosynthesis of collagen types I and IV, since the response to high glucose is significantly reduced by the neutralizing anti-TGF- $\beta$ antibody.

Diabetic glomerulopathy is characterized by expansion of the mesangial matrix and thickening of the glomerular basement membrane $(3,7)$. Structural-functional relationships have convincingly demonstrated that the degree of glomerulosclerosis, particularly in the mesangial area, is closely associated with the deterioration of renal function in diabetic nephropathy $(5,6)$. Experimental models of diabetes mellitus have provided evidence that increased synthesis of many extracellular matrix components is a likely event during the earlier stages of kidney involvement. Northern blot analysis on RNA derived from renal cortical tissue of diabetic animals has revealed increased transcript levels for type IV collagen chains $\alpha 1$ (IV) (10,11) and $\alpha 2$ (IV) (11), laminin B1 (12), and fibronectin (13). More recently, Fukui et al. (14) extended these studies to preparations of isolated glomeruli from kidneys of streptozotocin-diabetic rats. The latter study reported a general increase in the steady-state levels of mRNA encoding $\alpha$ (IV) collagen, laminin B1 and B2, as well as the $\alpha 1$ (I) and $\alpha 1$ (III) chains of the interstitial collagens types I and III (14). That these increased mRNA levels were directly caused by the metabolic consequences of the diabetic state was supported by the near complete reversal of the observed changes with insulin treatment (14).

The important role of hyperglycemia in the genesis of diabetic renal disease has been strengthened by the application of tissue culture techniques in the examination of the effects of ambient glucose levels on renal cells in culture. Recent studies on rat and human cultured mesangial cells showed that high glucose in the culture medium, independent of an osmotic effect, stimulated protein synthesis and mRNA levels of collagen type IV, laminin, and fibronectin $(18,19,21,22)$. Our studies show that high glucose stimulates the synthesis of collagen type I, as well as type IV. While the expression of interstitial type I 
collagen is not thought to be constitutive in normal mesangial cells in vivo, its synthesis is often induced after mesangial cell injury, whether by the in vitro culture conditions or by disease $(35,36)$ including diabetes mellitus (14).

The net effect of TGF- $\beta$ in various cell lines is to promote extracellular matrix deposition by stimulating the synthesis of matrix proteins, increasing the activity of tissue inhibitor of matrix-degrading metalloproteinases, and/or inhibiting the expression of stromelysin, which is an enzyme involved in the metabolism of extracellular matrix (29-32). Previous studies performed in cultured mesangial cells have revealed that exogenous TGF- $\beta$ increases the production of collagens, fibronectin, and the proteoglycans biglycan and decorin $(41,42)$. TGF- $\beta$ also increases transcripts of type I and IV collagen in primary cultures of rat mesangial cells (43). One likely explanation for the observed TGF- $\beta$-mediated increase in collagen gene expression is through transcriptional activation brought about by interactions of regulatory DNA sequences of the collagen gene with nuclear trans-acting factors $(44,45)$.

TGF $-\beta$ is produced by a variety of cells including several renal cell types ( reviewed in references 31,32 ). In the adult rat kidney the glomeruli express high mRNA and protein levels of TGF- $\beta_{1}$, and to a lesser extent TGF- $\beta_{2}(31,32)$. Moreover, all three glomerular cell types, endothelial, epithelial, and mesangial, have been shown to respond to the actions of TGF- $\beta_{1}$ in cell culture $(31,32,41,42)$. Accordingly, it appears that the TGF- $\beta$ system in the glomerulus normally functions in a paracrine or autocrine mode. Several factors may influence the production of a latent or bioactive form of TGF- $\beta$, as well as the availability of active TGF- $\beta$ to the target cell in the glomerular microenvironment. The extracellular matrix produced in the glomerular tuft, including proteoglycans such as decorin, can bind TGF- $\beta$ and, therefore, modulate its bioactivity $(27,32$, $41,46)$. The role of this matrix-TGF- $\beta$ interaction in determining the bioactivity of TGF- $\beta$ in diabetic glomerulopathy remains unknown. Moreover, it is possible that the process of nonenzymatic glycosylation could also impart an additional influence on the interaction between modified matrix protein components and TGF- $\beta$. It has been previously reported that nonenzymatic glycosylation of mesangial cell matrix produced by prolonged exposure to elevated glucose levels decreases the growth of cultured mesangial cells (15). It may be speculated that this altered mesangial matrix may exhibit specific characteristics of binding with TGF- $\beta$ allowing for its storage, timedrelease, and subsequent action, including inhibition of cellular proliferation and stimulation of glomerular extracellular matrix components.

Stimulation of extracellular matrix protein synthesis by high glucose is not only a feature of mesangial cells but also occurs in cultured proximal tubular cells incubated in the presence of $450 \mathrm{mg} / \mathrm{dl}$ glucose $(16,17)$. Whether this latter stimulatory effect is also mediated by autocrine activation of TGF- $\beta$ requires further studies, but it is relevant to note that the action of high glucose to inhibit proximal tubule cell proliferation ( 16 , $17,25)$ has also been shown to be mediated by endogenous TGF- $\beta$ (24). This may imply that this cytokine in the kidney may play a broader role in the manifestations of diabetes as expressed by both tubulointerstitial and glomerular structures.

The present set of studies have identified TGF- $\beta$ as one of the important cytokines that may mediate the stimulatory effects of high ambient glucose on collagen synthesis in cultured mesangial cells. We have also recently demonstrated that angio- tensin II-induced hypertrophy in murine proximal tubule cell culture is mediated by autocrine activation of TGF- $\beta$ (47). The present studies do not exclude the potential participation of other factors. Moreover, the precise role of TGF- $\beta$ in vivo remains to be established, and extrapolation to the in vivo situation is difficult because of limitations inherent in all short-term studies using tissue culture. It is interesting to note, however, that in two rodent models of spontaneous insulin-dependent diabetes (NOD mouse and BB rat), we have recently demonstrated that within few days of the appearance of hyperglycemia there is an increase in the expression of TGF- $\beta_{1}$ in the kidney that correlates with renal hypertrophy (48). Whether this renal increase of TGF- $\beta$ participates in the increased production and deposition of extracellular matrix proteins in vivo deserves additional studies.

In summary, the present set of studies provides evidence that the stimulation of extracellular matrix proteins in cultured mesangial cells by high glucose media is mediated by autocrine production of TGF- $\beta$. Since recent in vivo studies in a model of proliferative glomerulonephritis have demonstrated the feasibility of antagonizing glomerular TGF- $\beta$ bioactivity and ameliorating the progression of disease $(27,28)$, it is conceivable that similar strategies can also be developed for the treatment of nonimmune glomerular diseases such as diabetic glomerulopathy.

\section{Acknowledgments}

This work was supported in part by the National Institutes of Health (NIH) grants DK-39565, DK-44513, and DK-45191, and Training Grant DK-07006. K. Sharma is a recipient of a National Research Service Award from the NIH.

\section{References}

1. Hostetter, T. H. 1986. The progressive nature of renal disease. In Contemporary Issues in Nephrology. W. E. Mitch, editor. Churchill-Livingstone, Inc., New York. pp. 149-166.

2. Kreisberg, J. I., and S. H. Ayo. 1993. The glomerular mesangium in diabetes mellitus. Kidney Int. 43:109-113.

3. Nerlich, A., and E. Schleicher. 1991. Immunohistochemical localization of extracellular matrix components in human diabetic glomerular lesions. Am. J. Pathol. 139:889-899.

4. Ziyadeh, F. N., S. Goldfarb, and E. F. O. Kern. 1989. Diabetic nephropathy: metabolic and biochemical mechanisms. In Contemporary Issues in Nephrology 20. The Kidney in Diabetes Mellitus. B. M. Brenner and J. H. Stein, editors Churchill-Livingstone, Inc., New York. pp. 87-113.

5. Mauer, S. M., M. W. Steffes, E. N. Ellis, D. E. R. Sutherland, D. N. Brown, and F. C. Goetz. 1984. Structural-functional relationships in diabetic nephropathy. J. Clin. Invest. 74:1143-1155.

6. Osterby, R. 1992. Glomerular structural changes in type I (insulin-dependent) diabetes mellitus: causes, consequences, and prevention. Diabetologia. 35:803-812.

7. Steffes, M. W., R. W. Bilous, D. E. R. Sutherland, and S. M. Mauer. 1992. Cell and matrix components of the glomerular mesangium in type I diabetes. Diabetes. 41:679-684.

8. Ziyadeh, F. N., and S. Goldfarb. 1991. The renal tubulointerstitium in diabetes mellitus. Kidney Int. 39:464-475.

9. Ziyadeh, F. N. 1993. Renal tubular basement membrane and collagen type IV in diabetes mellitus. Kidney Int. 43:114-120.

10. Ihm, C. G., G. S. L. Lee, C. C. Nast, A. Artishevsky, R. Guillermo, P. S. Levin, R. J. Glassock, and S. G. Adler. 1992. Early increased renal procollagen $\alpha 1$ (IV) mRNA levels in streptozotocin induced diabetes. Kidney Int. 41:768777.

11. Ledbetter, S., E. J. Copeland, D. Noonan, G. Vogeli, and J. R. Hassell. 1990. Altered steady-state mRNA levels of basement membrane proteins in diabetic mouse kidneys and thromboxane synthase inhibition. Diabetes. 39:196203.

12. Poulsom, R., M. Kurkinen, D. J. Prockop, and R. P. Boot-Hanford. 1988. Increased steady-state levels of laminin B1 mRNA in kidneys of long-term strep- 
tozotocin-diabetic rats. No effect of aldose reductase inhibitor. J. Biol. Chem. 263:10072-10076.

13. Roy, S., R. Sala, E. Cagliero, and M. Lorenzi. 1990. Overexpression of fibronectin induced by diabetes or high glucose: phenomenon with a memory. Proc. Natl. Acad. Sci. USA. 87:404-408.

14. Fukui, M., T. Nakamura, I. Ebihara, I. Shirato, Y. Tomino, and H. Koide 1992. ECM gene expression and its modulation by insulin in diabetic rats. Diabetes. 41:1520-1527.

15. Crowley, S. T., M. Brownlee, D. Edelstein, J. A. Satriano, T. Mori, P. C Singhal, and D. O. Schlondorff. 1991. Effects of nonenzymatic glycosylation of mesangial matrix on proliferation of mesangial cells. Diabetes. 40:540-547.

16. Ziyadeh, F. N., D. A. Simmons, E. R. Snipes, and S. Goldfarb. 1991 Effect of myoinositol on cell proliferation and collagen transcription and secretion in proximal tubule cells cultured in elevated glucose. J. Am. Soc. Nephrol. 1:1220-1229.

17. Ziyadeh, F. N., E. R. Snipes, M. Watanabe, R. J. Alvarez, S. Goldfarb, and T. P. Haverty. 1990. High glucose induces cell hypertrophy and stimulates collagen gene transcription in proximal tubule. Am. J. Physiol. 259:F704-F714

18. Ayo, S. H., R. A. Radnik, J. A. Garoni, W. F. Glass II, and J. I. Kreisberg. 1990. High glucose causes an increase in extracellular matrix proteins in cultured mesangial cells. Am. J. Pathol. 136:1339-1348.

19. Ayo, S. H., R. A. Radnik, W. F. Glass II, J. A. Garoni, E. R. Rampt, D. R Appling, and J. I. Kreisberg. 1991. Increased extracellular matrix synthesis and mRNA in mesangial cells grown in high-glucose medium. Am. J. Physiol. 260:F185-F191.

20. Danne, T., M. J. Spiro, and R. G. Spiro. 1993. Effect of high glucose on type IV collagen in cultured rat glomerular epithelial, endothelial, and mesangial cells. Diabetes. 42:170-177.

21. Haneda, M., R. Kikkawa, N. Horide, M. Togawa, D. Koya, N. Kajiwara A. Ooshima, and Y. Shigeta. 1991. Glucose enhances type IV collagen production in cultured rat glomerular mesangial cells. Diabetologia. 34:198-200.

22. Nahman, N. S., K. L. Leonhart, F. G. Cosio, and C. L. Hebert. 1992 Effects of high glucose on cellular proliferation and fibronectin production by cultured human mesangial cells. Kidney Int. 41:396-402.

23. Studer, R. K., P. A. Craven, and F. R. DeRubertis. 1993. Role of protein Kinase $\mathrm{C}$ in the mediation of increased fibronectin accumulation by mesangial cells grown in high-glucose medium. Diabetes. 42:118-126.

24. Rocco, M. V., Y. Chen, S. Goldfarb, and F. N. Ziyadeh. 1992. Elevated glucose stimulates TGF- $\beta$ gene expression and bioactivity in proximal tubule. Kidney Int. 41:107-114.

25. Wolf, G., E. G. Neilson, S. Goldfarb, and F. N. Ziyadeh. 1991. The influence of glucose concentration on angiotensin II-induced hypertrophy of proximal tubular cells in culture. Biochem. Biophys. Res. Commun. 176:902909.

26. Wolf, G., K. Sharma, Y. Chen, M. Ericksen, and F. N. Ziyadeh. 1992. High glucose-induced proliferation in mesangial cells is reversed by autocrine TGF- $\beta$ Kidney Int. 42:647-656.

27. Border, W. A., S. Okuda, L. R. Languino, M. B. Sporn, and E. Ruoslahti. 1990. Suppression of experimental glomerulonephritis by antiserum against transforming growth factor $\beta_{1}$. Nature (Lond.) 346:371-374.

28. Border, W. A., N. A. Noble, T. Yamamoto, J. R. Harper, Y. Yamaguchi, M. D. Pierschbacher, and E. Rusolahti. 1992. Natural inhibitor of transforming growth factor- $\beta$ protects against scarring in experimental kidney disease. Nature (Lond.) 360:361-364.

29. Kerr, L. D., D. B. Miller, and L. Matrisian. 1990. TGF- $\beta_{\text {, inhibition of }}$ transin/stromelysin gene expression is mediated through a fos binding sequence. Cell. 61:267-278.

30. Roberts, A. B., B. K. McCune, and M. B. Sporn. 1992. TGF- $\beta$ : Regulation of extracellular matrix. Kidney Int. 41:557-559.
31. Rocco, M. V., and F. N. Ziyadeh. 1991. Transforming growth factor-beta: an update on systemic and renal actions. In Hormones, Autacoids, and the Kidney. Contemporary Issues in Nephrology. S. Goldfarb and F. N. Ziyadeh, editors. Churchill-Livingstone, Inc., New York. pp. 391-410.

32. Sharma, K., and F. N. Ziyadeh. 1993. The transforming growth factor- $\beta$ system and the kidney. Sem. Nephrol. 13:116-128.

33. Wolf, G., U. Haberstroh, and E. G. Neilson. 1992. Angiotensin II stimulates the proliferation and biosynthesis of type I collagen in cultured murine mesangial cells. Am. J. Pathol. 140:95-107.

34. Wolf, G., F. Thaiss, W. Schoeppe, and R. A. K. Stahl. 1992. Angiotensin II-induced proliferation of cultured murine mesangial cells: inhibitory role of atrial natriuretic peptide. J. Am. Soc. Nephrol. 3:1270-1278.

35. Haralson, M. A., H. R. Jacobson, and R. L. Hoover. 1987. Collagen polymorphism in cultured rat kidney mesangial cells. Lab. Invest. 57:513-523.

36. Ohyama, K., J. M. Seyer, R. Raghow, and A. H. Kang. 1990. Extracellular matrix phenotype of rat mesangial cells in culture. Biosynthesis of collagen types I, III, IV, and V and a low molecular weight collagenous component and their regulation by dexamethasone. J. Lab. Clin. Med. 116:219-227.

37. Scherberich, J. E., P. Fischer, A. Bigalke, P. Stangl, G. Wolf, M. Haimerl and W. Schoeppe. 1989. Routine diagnosis with PhasSystem compared to conventional electrophoresis: automated sodium dodecyl sulfate-polyacrylamide gel electrophoresis, silver staining and Western blotting of urinary proteins. Electrophoresis. 10:58-62.

38. Wolf, G., and E. G. Neilson. 1990. Angiotensin II induces cellular hypertrophy in cultured murine proximal tubular cells. Am. J. Physiol. 259:F768F777.

39. Liau, G., Y. Yamada, and B. De Crombrugghe. 1985. Coordinate regulation of the levels of type III and type I collagen mRNA in most but not all mouse fibroblasts. J. Biol. Chem. 260:531-536.

40. Myers, J. C., J. M. Brinker, N. A. Kefalides, J. Rosenbloom, S. Y. Wang, and L. J. Gudas. 1986. Discrimination among multiple AATAAA sequences correlates with interspecies conservation of select $3^{\prime}$ untranslated nucleotides. Nucleic Acids Res. 14:4499-4517.

41. Okuda, S., L. R. Languino, E. Ruoslahti, and W. A. Border. 1990. Elevated expression of transforming growth factor- $\beta$ and proteoglycan production in experimental glomerulonephritis. J. Clin. Invest. 86:453-462.

42. MacKay, K., L. J. Striker, J. W. Stauffer, T. Doi, L. Y. Agodoa, and G. E. Striker. 1989. Transforming growth factor- $\beta$. Murine glomerular receptors and responses of isolated glomerular cells. J. Clin. Invest. 83:1160-1167.

43. Ishimura, E., R. B. Sterzel, and M. Kashgarian. 1990. Effect of transforming growth factor (TGF) $-\beta$ on extracellular matrix (ECM) production by cultured rat mesangial cells (abstract). Kidney Int. 37:197.

44. De Chrombrugghe, B., G. Karsenty, S. Maity, T. Vuorio, P. Rossi, E. C. Ruteshouser, S. H. McKinney, and G. Lozano. 1990. Transcriptional mechanisms controlling types I and III collagen genes. Ann. NY Acad. Sci. 580:88-96.

45. Kuncio, G. S., P. Killen, and E. G. Neilson. 1990. Modulated expression of the $\alpha$ I (IV) collagen gene in murine tubular cells cultured with fibrosis-relevant cytokines (abstract). J. Am. Soc. Nephrol. 1:551.

46. Paralkar, V. M., S. Vukicevic, and A. H. Reddi. 1991. Transforming growth factor $\beta$ type I binds to collagen IV of basement membrane matrix: implication for development. Dev. Biol. 143:303-308.

47. Wolf, G., E. Mueller, R. A. K. Stahl, and F. N. Ziyadeh. 1993. Angiotensin II-induced hypertrophy of cultured murine proximal tubular cells in culture. $J$. Clin. Invest. 92:1366-1372.

48. Sharma, K., M. Ericksen, S. Goldfarb, and F. N. Ziyadeh. 1992. Up-regulation of kidney transforming growth factor- $\beta$ (TGF- $\beta$ ) gene expression in two rodent models of spontaneous diabetes mellitus. J. Am. Soc. Nephrol. 3:766. (Abstr.) 